\title{
TURKISH NATIONALISM, IDENTITY AND FOREIGN POLICY IN COMPARATIVE PERSPECTIVE
}

\section{EDITORIAL INTRODUCTION}

\author{
EREN ÖZALAY-ŞANLI" \\ Bahçeşehir University
}

\author{
AYŞEN CANDAŞ ${ }^{* * *}$ \\ Boğaziçi University
}

Research on nationalism, post-cold war changes that led to the proliferation of new identities and the ever interesting terrain of foreign policy have dominated the field of political science in general and international relations in particular for at least two decades. As the post-cold war political atmosphere has revealed itself, it has become apparent that the bipolar world that defined it is no longer a valid explanation for the future. Hence a quest for a new identity paradigm in an entirely transformed world of the new terrain of foreign policy has kept the scholars of political science busy in Turkey and at the international level. The search for alternative paradigms harvested original research that inquired into issues and areas that were untapped before. These have ranged from extensive discourse analysis of political texts to indicators of religiosity which depicted long forgotten dimensions of collective identity that leave behind and transcend the options of the previous era, i.e., being either part of the "communist" bloc or the "free" world.

The articles in this issue of the Boğaziçi Journal: Review of Social, Economic and Administrative Studies are from the proceedings of the $2^{\text {nd }}$ Graduate Workshop of the Department of Political Science and International Relations. The articles that are included in this volume answer, evaluate and build on the aforementioned quest for alternative explanations to nationalism, identity-formation and foreign policy formulations in Turkey. This annual graduate conference began with the idea of bringing graduate students with a research focus on Turkish politics together under the same roof. The organization committee consisting of graduate students of the department, assisted by the department faculty, called for papers from a broad range of topics ranging from economic policy to political parties and from governance to democratization.

These articles demonstrate that questions inquiring into the causes and consequences of nationalism, the proliferation of new identities, and questions of change and continuity in foreign policy dominate and are at the center of political science research carried out in and about Turkey. The nine articles selected for publication in this issue were chosen along this thematic focus and each seeks to present outcomes of recent original research carried out in Turkey by graduate students. The first two articles by Eren Özalay-Şanlı and Alp Köksal consider the once heated but now calmed debate of Turkey's

* Eren Özalay-Şanl1 is a Ph.D. candidate in the Department of Political Science and International Relations at Boğaziçi University, Bebek, 34342, İstanbul, Turkey and a Research Assistant in the Department of EU Studies at Bahçeşehir University, Beşiktaş, 34353, İstanbul, Turkey. E-mail: eren.ozalay@ bahcesehir.edu.tr

** Ayşen Candaş is an Assistant Professor in the Department of Political Science and International Relations at Boğaziçi University, Bebek, 34342, İstanbul, Turkey. E-mail: aysen.candas@boun,edu.tr 
accession process to the European Union. The following articles by Ebru Eren-Webb, Sercan Gidişoğlu, Kerem Rızvanoğlu and Şermin Korkusuz offer insights about nationalism in Turkey and newly rising formulations of identity in Turkey, complemented by the article by Ilia Xypolia on Turkish Cypriot identity. The last three articles by Altay Atlı, Rahime Süleymanoğlu-Kürüm and Murat Güneylioğlu are on the recent developments in the foreign policy agenda of Turkey, a debate which is as interesting as it is heated and is expected to attract even more attention in the days to come.

The paper by Eren Özalay-Şanlı assesses the developments in current Turkish politics by comparing analytical frameworks offered by democratization and Europeanization theories concerning the recent reforms of education in Turkey. The author discusses the assumptions of Europeanization and democratization theories and then debates whether these theoretical approaches answer and are able to explain the education reforms in Turkey in the period after Turkey's candidacy was announced in the 1999 Helsinki Summit of the European Union. Education policy is vital for the fact that it remains within almost complete supervision of nation states in an ever globalized world, and standardization of education policy would further integrate Europe as more policies enter the competence of the Union. However, as in every policy area, education is affected by international and transnational political influences as values of the new political order are reflected in the policy and content of education as well. Through an examination of recent education reforms in Turkey, the author analyzes the types of reforms that are debated in Turkey whose contents are informed by an amalgam of demands from European Union institutions. These are part of the accession negotiations and include societal demands channeled through civil society organizations and a pressing need from the market on the necessary skills to implant on the workforce. The findings show that the reforms meet the demands of the EU institutions and the needs of the business and market without any problems. However, societal claims remain unanswered as they clash with the fault lines of Turkish politics that have not gone through the necessary mentality change that Europeanization necessitates. The findings of the paper reveal that the norm diffusion model developed by the scholarship of Europeanization is more suitable to explain the democratization process and education reforms in Turkey than other models.

The paper by Alp Köksal is a thorough analysis of macro level indicators that are employed to compare Turkey and various EU member states in order to evaluate whether the offer of a strategic partnership is a sincere proposition by the current European decision makers or whether it is an example of double standards as is popularly perceived in Turkey. By using demographic, economic, political, security and societal indicators derived from Eurobarometer surveys, Eurostat and other sources to pursue a systematic comparison, the author tries to answer the question of whether Turkey is really different from the member states. His analysis consists of two groups, that of old member states which are politically and economically powerful and the newcomers of the Central and Eastern European enlargement which he assumes would present the most similar cases to Turkey. In conclusion, the study finds that the proposition of a "strategic partnership" is not necessarily born out of the bias of Europeans, as there are profound differences even with CEECs; thus valid grounds exist on the EU side for suggesting a special formula. The author suggests that although Turkey has gone through a remarkable transformation on its dedicated path towards full membership into the EU, Turkish authorities must ambitiously undertake further reforms for closing the gap that exists between Europe and Turkey, or privileged partnership will remain as a fair proposition.

Ebru Eren-Webb's paper is a content analysis of the recent Eurasianist discourse in Turkey. Eurasianism has a long history in Turkish politics; however it has gained new momentum after the paradigm 
changes with the end of the Cold War and the political vision of shifting foreign policy orientation of Turkey from being solely Western oriented to an intensified focus on its immediate neighborhood. By employing the analytical framework offered by critical geopolitics theory, the author compares the different perspectives of Eurasianism that are represented by the discourses of three journals (the nationalist Türk Yurdu, the socialist Teori, and the conservative democrat Türkiye Günlüğ̈̈̈) between 1990 and 2010. The author argues that the geopolitical visions of these three groups and the way they imagine the past help to explain their respective perspectives of Eurasia and how they place Turkey in these perspectives. In addition, the author's findings lead her to conclude that the nationalist and socialist visions of Eurasianism did converge on each other because the Islamist circles in the PostCold War allied with the liberal groups and developed a "counter-memory" of the past that became an alternative to the Kemalist historiography, while nationalist and socialist geopolitical traditions remained faithful to the Kemalist narrative of the past. This article therefore is an attempt to analyze different nationalist perspectives which seek to reformulate an identity for Turkey in the post-Cold War period and legitimize different ideological currents by employing alternative and competing readings of the past.

The authors Sercan Gidişoğlu and Kerem Rızvanoğlu present another analysis of political discourse in Turkey, that of nationalist websites on the internet. The article is invaluable considering the ever increasing use of social media in Turkey as a way of individual political reaction and participation. The content and form of political practice, revealed reactions and calls for action that take place in the internet environment constitute another field of research for the scholars of Turkish nationalism and identity. In their analysis of the 121 websites which combine frameworks offered by political science and new media studies, the authors offer a typology of the network structure of what they define as "online Turkish nationalism." This interdisciplinary typology not only promises to benefit those who would conduct further research on online nationalism, but those who research on other discursive nationalist representations as well. Based on their findings, the authors argue that Turkish nationalists use the Internet mainly in order to diffuse their ideology, to strengthen Turkish national identity and nationalist community structure and finally to build a dedicated virtual community. To realize these purposes, as the authors depict, Turkish nationalists benefit from various content categories. Findings also reveal that the visual layouts of the web sites provide opportunities for the reconstruction of a manipulated interaction oriented towards reinforcing the prevalent nationalist ideology.

The paper by Ilia Xypolia enriches the debate on Turkish identity and nationalism by adding the Turkish Cypriot dimension in the general comparative framework of the conference and is an attempt which would help overcome the neglect of the locality and the distinction of the Turkish Cypriot experience. In the academia too, the issues of Turkish Cypriot identity remain unproblematized although further research in this vein would reveal significant historical aspects of Turkish nationalism itself. This study questions the assumption that is usually taken for granted considering the Turkish Cypriot population (often also the case with Turkey) as a homogeneously secular community. The author argues that the secular identity of Turkish Cypriots is quite a recent development because the Turkish Cypriot community was not cohesive under the British rule during the interwar period of 1919-1939. The impact of the Republican reforms was not clear cut and led to a divide in the society between traditionalists and secularists as the British rule was siding with the traditionalists. This analysis presents an excellent case for the comparativists and historians of identity as it depicts the implication of Turkish nationalism without the presence of the Kemalist rule and where a societal competition of two opposing political ideas, one siding with the British rule, did actually take place, 
unlike the single party ban of all opposition in Turkey in 1930s. The author argues that the 1930s was the crucial decade in the development of a Turkish Cypriot secular identity, as the internal conflict came to end after the Second World War with the victory of the secularists.

The paper by Şermin Korkusuz tackles the discourse of the Nationalist Action Party (MHP) concerning Turkey-EU relations in the period between 1990 and 2008. This was a time when the globalization process that Turkey was going through along with the EU accession process as well as the debates about transferring sovereignty to supranational organizations intensified. By identifying the prominent themes in the discourse of the MHP, which is assumed to be the radical nationalist and openly antiWest party in Turkey, the author argues that the position that the MHP holds with regards to the EU has changed over the time period analyzed in this paper. This change was mainly due to how the party perceived the European Community/Union in different periods. While the party perceived the Community as an economic organization earlier, the later perceptions of the party regarded the EU as a political union inheriting a corrupt civilization. Another interesting finding is that, although the MHP almost always had a negative opinion of the EC/EU, it never put the EU relations consideration completely aside. The article's finding is significant in a way that even the radical nationalist party is responsive to the EU accession process and has not totally alienated itself from this perspective.

Addressing globalization literature, as did the previous article, Murat Güneylioğlu examines globalization's effects on the changing nature of Turkey's approach to the Middle East in general and towards Syria in particular. The author first draws attention to the 1990s when Turkish foreign policy was shaped by realist parameters as the country relied on an alliance with Israel and employed hard-power seeking deterrence and coercion. In the 2000s, with Syria's signing of a counter-terrorism accord in 1998, the two states carried their relationship to high levels of collaboration in many realms, which the author argues was a late response to globalization's challenge to traditional foreign policy formation. The author comments that the Justice and Development Party (AKP) government tried to utilize Turkey's soft-power as complementary to hard-power and Turkey expressed its willingness to launch an economic integration with Syria, as the bilateral trade volume boosted and the two states lifted the visas and built common action plans. The author concludes that, with these efforts, Turkey tried to transform its material power into a structural one supported by non-state economic actors, and that Turkey also realized the need for a proactive policy as it launched a Syria-Israel mediation process with a regional peace-building vision, because the external acceptance of legality of foreign policy gained prominence in global information age. These efforts do not remain unquestioned as Turkey's structural and soft-power has limitations in that its attractiveness is closely linked with a successful maintenance of Europeanization process. The aftermath of the "Arab Spring" will bring important insights on whether the optimistic stance adopted in this article regarding Turkey's softpower potential in the region will be actualized or not.

In his article on foreign economic policy, Altay Atli takes up the issue of business associations and their impact on the foreign policy of Turkey. The article's contribution is the analytical perspective of the so-called "Özal model" and its implications in foreign economic policy. The article considers not only the empirical relevance of the "Özal model" but also places the impact of this model within the larger context of the relevant literature on the businessmen associations' impact on foreign policy as these act as an economic interest group. Whether and to what extent the current foreign economic policy under the current government is similar to the Özal model comprises the comparative aspect of this paper where the author presents a thorough analysis of the current foreign economic policy 
under the AKP. The analytical framework used by the author evaluates the foreign policy participation of business actors at three levels, i.e. structural, domestic, and the individual level. The framework proposed in the paper incorporates the factors of state capability, business power and issue salience as determinants of policy influence at the domestic level. Within this context, a typology of roles assumed by business associations is referred to in order to identify the different policy areas where the business is active. As a result, the paper finds that while there are similarities between the two periods in the sense that in both cases business actors are actively taking part in foreign policy issues, there are also significant divergences due to increased interdependence at the international level, and transformation of Turkish economy and 'consolidation of democracy' in Turkey.

The article by Rahime Süleymanoğlu-Kürüm examines the efforts of mediation and good offices, two methods identified by the United Nations as mechanisms for the peaceful settlement of disputes as a new aspect of Turkish foreign policy. In questioning the argument that Turkish foreign policy is increasingly influenced by the EU accession process since the Helsinki Summit in 1999, the author argues that the changes in Turkish foreign policy can be better evaluated by using good offices and mediation efforts by the foreign policy actors as they reveal changing foreign policy norms and goals, instruments and style and procedures. Resting on the assumption that an increase in the intensity of good offices and mediation activities by the foreign policy actors of a particular country indicates a change in foreign policy towards a peaceful and normative approach, the author takes into account troika meetings within the context of good offices as they are intended to build confidence between the conflicting parties. In applying these assumptions to Turkey, the author analyzes the evolution of the Turkish mediation since 1987 when Turkey applied for the full membership in the EEC and evaluates the change in the intensity and quality of Turkish mediation as well as her acceptance as a mediator by the parties involved in regional conflicts. The data analyzed makes use of journal articles on the issue. Like the previous article, this one points to the Özal period as the beginning of these efforts, and the author concludes that the foreign policy mediation is possible when the actor's domestic capacity is improved and policy makers gain confidence with both factors becoming more prominent under the subsequent AKP governments. 